\title{
IMPLEMENTASI PENDEKATAN SAINTIFIK DALAM PEMBELAJARAN PAI DI SMP NEGERI 2 DAN SMP NEGERI 5 KOTA BANDUNG TAHUN 2015
}

\author{
Sulastri, * \\ Udin Supriadi, Munawar Rahmat \\ Program Studi Ilmu Pendidikan Agama Islam, \\ Fakultas Pendidikan Ilmu Pengetahuan Sosial, Universitas Pendidikan Indonesia \\ *Email : sulastrilikasophia@gmail.com
}

\begin{abstract}
ABSTRAK
Penelitian ini dilatar belakangi oleh masalah guru PAI yang kebanyakan masih belum paham secara menyeluruh bagaimana mengimplementasikan pendekatan saintifik yang menjadi ciri khas kurikulum 2013 dalam pembelajaran PAI di sekolah. Pendekatan saintifik memiliki beberapa langkah yang harus dilaksanakan diantaranya adalah mengamati, menanya, mencari informasi, mengkomunikasikan, dan menyimpulkan. Langkah-langkah tersebut harus ada dalam perencanaan dan pelaksanaannya, pengimplementasian langkah-langkah inilah yang menjadi fokus utama pembahasan penelitian ini. Adapun sekolah yang menjadi objek penelitian, yaitu SMPN 2 dan SMPN 5 Bandung dengan guru PAI sebagai subjek penelitiannya. Peneliti akan membahas perencanaan pembelajaran saintifik dalam RPP yang telah dibuat oleh guru PAI dan implementasinya dalam pembelajaran PAI di kelas. Penelitian ini bertujuan untuk mengetahui perencanaan pembelajaran saintifik pada RPP berdasarkan kurikulum 2013 dan implementasi pelaksanaan langkah-langkah pendekatan saintifik dalam pembelajaran PAI. Pendekatan penelitian yang digunakan adalah pendekatan kualitatif dengan metode deskriptif kualitatif. Teknik pengumpulan data penelitian ini dengan menggunakan observasi, wawancara, dan studi dokumentasi. Adapun teknik analisis data menggunakan teknik menurut pendapat Miles and Hubermen, yaitu reduksi data, display data, dan verifikasi/kesimpulan. Data yang diperoleh dari lapangan menunjukan bahwa RPP yang telah dibuat sudah sesuai berdasarkan sistematika kurikulum 2013. Data hasil observasi juga menunjukan bahwa guru PAI telah melaksanakan langkah-langkah saintifik dengan baik. Mereka menggunakan media untuk proses mengamati, menggunakan teknik motivasi dan reward untuk menstimulasi siswa agar aktif bertanya dan berkomunikasi, serta guru menggunakan teknik presentasi dan konsep student center saat pembelajaran agar siswa aktif berbicara dan mengemukakan pendapat, sehingga diakhir pembelajaran siswa dapat menyimpulkan sendiri pembelajaran pada pertemuan itu. Guru juga terus membimbing dan melakukan penilaian terhadap siswa selama proses pembelajaran berlangsung.
\end{abstract}

Kata Kunci : Pendekatan Saintifik, Pembelajaran PAI, Langkah-Langkah Saintifik

TARBAWY, Vol. 2, Nomor 1, (2015)| 68 
PENDAHULUAN

\begin{abstract}
Kurikulum 2013 menggunakan pendekatan saintifik untuk proses pembelajaran dengan aktivitas mengamati, menanya, mengolah, menyajikan, menyimpulkan, dan mencipta. Aktivitas mengamati dan bertanya dapat dilakukan di kelas, sekolah, atau di luar sekolah sehingga kegiatan belajar tidak hanya terjadi di dalam ruang kelas. Dalam pendekatan ini, setiap siswa harus terlibat dalam sebuah proses ilmiah yang pada umumnya melibatkan pengamatan atau observasi yang dibutuhkan untuk pengumpulan data.
\end{abstract}

Pendekatan saintifik memang sangat identik dengan metode ilmiah. Misalnya, perolehan data, pengolahan data, dan penyampaian informasi juga membutuhkan kerja sama. Aktivitas utama tersebut merupakan ciri dari pembelajaran saintifik, menurut Dyer yang dikutip oleh Ridwan Sani (2014 : 53), keterampilan inovatif dalam pembelajaran saintifik meliputi, observasi, bertanya, melakukan percobaan, asosiasi, dan membangun jaringan. Berdasarkan teori Dyer tersebut (Sani, 2014, hal. 53), pendekatan saintifik dapat dikembangkan dalam pembelajaran yang memiliki komponen proses pembelajaran antara lain: mengamati, menanya, mencoba/mengumpulkan informasi, menalar/asosiasi, dan membentuk jejaring/melakukan komunikasi.

Jika dilihat dari langkah-langkah pendekatan saintifik, sepertinya akan mudah jika pendekatan ini diterapkan dalam mata pelajaran sains karena di dalamnya memang merupakan langkahlangkah yang sering digunakan dalam sains, seperti mengamati objek, mencari informasi, menalar, mencoba, dan seterusnya. Namun, bagaimana penerapan pendekatan ini pada mata pelajaran pendidikan agama Islam (PAI)?
Apakah pendekatan ini akan sulit diterapkan pada mata pelajaran PAI? Ataukah pendekatan ini akan efektif untuk pembelajaran PAI? Berawal dari pertanyaan tersebut, peneliti sangat tertarik untuk mengobservasi tentang penerapan pendekatan ini pada mata pelajaran PAI. Bagaimana cara guru yang sesungguhnya dalam menerapkan kurikulum yang baru ini karena berdasarkan fakta di lapangan, ternyata masih banyak guru yang merasa kesulitan dalam implementasi kurikulum 2013 ini. Sebagaimana tertulis pada sebuah artikel yang berjudul Tiga Masalah Guru dalam Implementasi Kurikulum 2013 yang diambil dari news okezone.com, bahwa:

"... masih banyak guru yang merasa kesulitan menerapkan pendekatan tersebut dalam mengajar. Pendapat tersebut disampaikan oleh Staf Khusus Menteri Pendidikan dan Kebudayaan (Mendikbud) Bidang Pengawasan dan Pengendalian Pembangunan (UKMP3), Agnes Tuti Rumiati, dalam Dialog dan Konsultasi Nasional terkait Kurikulum 2013. Dia menyebut, terdapat banyak hal yang belum dipahami tenaga pendidik terkait kurikulum 2013." (Puspitarini, 2014)

Masih dalam kutipan artikel tersebut, disebutkan juga bahwa masalah pertama para guru dalam mengimplementasikan kurikulum 2013 adalah proses penilaian yang dianggap rumit. Kedua, para guru masih kesulitan menerapkan scientific approach dalam kegiatan belajar mengajar. Kendala ketiga adalah guru masih merasa kesulitan dalam membuat siswa aktif dalam pembelajaran.

Penelitian ini bertujuan untuk mengetahui bagaimana penerapan yang dilakukan oleh guru PAI di salah satu sekolah, dalam upayanya menerapkan pola pendekatan saintifik ini. Penelitian ini bukan untuk memberikan judgement baik atau buruk, tetapi untuk 
mendeskripsikan bagaimana guru tersebut mampu mengembangkan pola pendekatan saintifik dalam pembelajaran PAI, sehingga dapat menjadi tambahan referensi untuk setiap guru PAI dalam menerapkan pendekatan saintifik pada pembelajaran di kelas. Berdasarkan pengalaman peneliti sendiri, mengimplementasikan pendekatan saintifik khususnya dalam mata pelajaran PAI, memang tidak mudah ketika peneliti melaksanakan Program Pengalaman Lapangan (PPL). Melalui penelitian ini, diharapkan akan bermanfaat khususnya bagi peneliti dan umumnya bagi para pembaca untuk lebih mendalami lagi bagaimana implementasi pendekatan saintifik ini dengan baik.

Di dalam penelitian ini, akan dibahas mengenai lima langkah utama dalam pendekatan saintifik yang harus dilakukan oleh seorang guru dalam pembelajaran. Berdasarkan beberapa referensi yang peneliti dapatkan, ada yang menyebutkan lima-delapan langkah pendekatan saintifik dalam pembelajaran. Tetapi, peneliti akan mengerucutkannya menjadi lima langkah utama yang akan diobservasi kepada beberapa guru di sekolah yang telah dipilih yaitu, SMP Negeri 2 Bandung dan SMP Negeri 5 kota Bandung.

Berdasarkan uraian di atas, sangat penting bagi seorang guru khususnya guru PAI untuk lebih memahami kembali cara penerapan pendekatan saintifik pada proses pembelajaran, sehingga tujuan dari adanya pendekatan saintifik ini dapat terealisasi dengan baik dan benar. Oleh karena itu, penelitian ini akan meneliti tentang bagaimana cara guru PAI mengimplementasikan pendekatan saintifik yang diangkat dalam judul Implementasi Pendekatan Saintifik dalam Pembelajaran PAI di SMPN 2 dan SMPN 5 Kota Bandung Tahun 2015.

Sebagaimana yang telah disebutkan sebelumnya, bahwa kurikulum 2013 ini sangat identik dengan sebuah pendekatan yang baru yang mungkin asing akan tetapi, langkahlangkah di dalamnya tidaklah asing dalam sebuah pembelajaran, yaitu pendekatan saintifik. Dalam beberapa referensi, banyak yang telah mengungkapkan definisi tentang pendekatan saintifik ini dan semua memang mengacu pada sebuah proses pembelajaran yang ilmiah. M. Hosnan mengatakan bahwa :

Pendekatan saintifik adalah proses pembelajaran yang dirancang sedemikian rupa agar peserta didik aktif mengkonstruksi konsep, hukum atau prinsip melalui tahapan-tahapan mengamati (untuk mengidentifikasi atau menemukan masalah), merumuskan masalah, mengajukan atau merumuskan hipotesis, mengumpulkan data dengan berbagai tekhnik, menganalisis data, menarik kesimpulan dan mengkomunikasikan konsep, hukum atau prinsip yang "ditemukan" (Hosnan, 2014, hal. 34).

Pendekatan saintifik berkaitan erat dengan metode saintifik. Metode saintifik pada umumnya melibatkan kegiatan pengamatan atau observasi yang dibutuhkan untuk perumusan hipotesis atau mengumpulkan data. Metode ilmiah ini pada umumnya dilandasi dengan pemaparan data yang diperoleh melalui pengamatan atau percobaan. Oleh sebab itu, kegiatan percobaan dapat diganti dengan kegiatan memperoleh informasi dari berbagai sumber (Sani, 2014, hal. $50)$.

Menurut Kuhlthau, Maniotes, dan Caspari (dalam Abidin, 2014, hal. 125), model pembelajaran proses saintifik merupakan model pembelajaran yang menuntut siswa beraktivitas sebagaimana seorang ahli sains. Dalam praktiknya siswa diharuskan melakukan serangkaian aktivitas selayaknya langkah-langkah penerapan metode ilmiah. Serangkaian aktivitas dimaksud meliputi merumuskan masalah, (2) mengajukan hipotesis, (3) mengumpulkan data, (4) 
mengolah dan menganalisis data, dan (5) membuat kesimpulan.

Barringer, et al. (dalam Abidin, 2014, hal. 125), mengungkapkan bahwa pembelajaran proses saintifik merupakan pembelajaran yang menuntut siswa berpikir secara sistematis dan kritis dalam upaya memecahkan masalah yang penyelesaiannya tidak mudah dilihat.

Pendekatan saintifik dalam pembelajaran sangat erat kaitannya dengan tata cara melaksanakan sebuah penelitian secara ilmiah. Sepintas terlihat sulit ketika harus menerapkan langkahlangkah yang ada pada sebuah penelitian, diterapkan pada sebuh proses pembelajaran. Akan tetapi, dengan adanya pendekatan ini, para siswa akan lebih kritis dalam memahami sebuah konsep pembelajaran. Mereka tidak hanya mendengarkan pengetahuan dari gurunya, tetapi juga diharuskan untuk mencari informasi atau data secara mandiri. Dengan harapan mereka akan lebih paham tentang konsep yang telah mereka temukan secara mandiri, bukan sekedar diberikan oleh guru.

Dengan adanya pendekatan saintifik pula, akan memberikan rasa ingin tahu yang tinggi terhadap siswa untuk lebih menggali informasi. Hal ini dikarenakan guru tidak memberikan konsep secara langsung melainkan hanya memberi pengarahan saja dalam pembelajaran, sementara siswa yang akan melaksanakan prosesnya. Dengan ini siswa akan berperan lebih aktif dalam sebuah pembelajaran, dimana mereka tidak hanya terpaku pada buku atau berdiam diri mendengarkan guru mengajar. Pendekatan saintifik ini akan sangat menstimulasi siswa untuk lebih aktif dalam sebuah pembelajaran.

\section{METODE}

Desain penelitian ini adalah desain studi kasus. Studi kasus adalah bentuk penelitian yang mendalam tentang suatu aspek lingkungan sosial termasuk manusia di dalamnya, dapat dilakukan pada seorang individu atau segolongan orang (Nasution, 2009, hal. 27). Dalam penelitian ini, studi kasus yang dilakukan akan memberi gambaran tentang keadaan yang ada pada sebuah pembelajaran PAI. Hal ini terkait dengan bagaimana cara guru PAI mengimplementasikan pola pendekatan saintifik dalam pembelajaran PAI tersebut sehingga peneliti dapat memperoleh informasi secara lengkap dan mendalam.

Berdasarkan pada pola desain studi kasus yang digunakan dengan tujuan penelitian deskriptif serta pendekatan yang telah dipilih yaitu pendekatan kualitatif maka penelitian ini menggunakan metode penelitian deskriptif atau metode penelitian deskriptif kualitatif. Penelitian deskriptif adalah penelitian yang bermaksud untuk membuat gambaran mengenai situasisituasi atau kejadian-kejadian dan mengakumulasikan data dasar dalam cara deskriptif (Suryabrata, 2012, hal. 76).

Penelitian ini berlokasi di SMPN 2 dan SMPN 5 kota Bandung. Adapun alamat dari SMP Negeri 2 Bandung ini berada di Jalan Sumatera No. 42, Kel. Merdeka, Kec. Sumur Bandung, Kota Bandung, Jawa Barat. Sedangkan SMP Negeri 5 Bandung berlokasi di Jalan Sumatera No. 40, Kel. Merdeka, Kec. Sumur Bandung, Kota Bandung, Jawa Barat. Jarak antara kedua SMP ini memang sangat dekat, sehingga peneliti memilih kedua SMP ini sebagai tempat penelitian karena lokasinya yang strategis dan jarak kedua sekolah ini pun dekat.

Subjek penelitian dalam penelitian ini adalah pihak yang menjadi sumber informasi bagi peneliti untuk memperoleh data secara menyeluruh, sebagai narasumber dalam penelitian ini. Dalam penelitian ini, narasumber utama adalah guru mata pelajaran PAI di SMP Negeri 2 dan SMP Negeri 5 kota 
Bandung. Peneliti akan melaksanakan penelitian pada dua orang guru PAI dari setiap sekolahnya.

Sebagaimana yang telah dijelaskan di atas, bahwa metode penelitian ini adalah deskriptif kualitatif, maka secara umum penelitian kualitatif paling sering menggunakan teknik pengumpulan data berupa observasi, wawancara, dan studi dokumentasi. Agar sesuai dengan desain dan metode yang digunakan maka penelitian ini juga menggunakan teknik pengumpulan data berupa observasi, wawancara, dan studi dokumentasi.

Teknik yang digunakan untuk menganalisis data diperoleh dari hasil wawancara, hasil observasi, dan hasil dokumentasi yaitu dideskripsikan secara narasi sesuai dengan kenyataan yang terjadi di lapangan. Adapun beberapa langkah yang ditempuh dalam mengadakan kegiatan analisis data peneliti menggunakan langkah-langkah yang dikemukakan oleh Miles \& Huberman yang terdiri dari tiga tahapan, yaitu reduksi data, display data, dan kesimpulan/verifikasi.

Pada setiap teks data penelitian, peneliti memberi label yang terkait dengan kumpulan teks tersebut. Kemudian kode-kode tersebut diklasifikasikan dan dianalisis lebih lanjut. Adapun manfaat dari pengodean ini adalah merinci, menyusun konsep, dan membahas kembali semuanya (Gunawan, 2013, hal. 241). Dengan dibuatnya pengodean ini, memudahkan peneliti dalam menganalisis data yang telah tersusun rapi. Menurut Richards yang dikutip oleh Sarosa, kode adalah mereduksi data menjadi simbol yang mewakilinya (Sarosa, 2012, hal. 73). Miles \& Huberman mendefinisikan kode sebagai label yang diberikan sebagai unit pemberian makna atas informasi yang dikomplikasi dalam penelitian (Sarosa, 2012, hal. 73). Adapun koding untuk sumber data, Observasi: O, Wawancara:
W, Studi Dokumentasi: D. Koding untuk jenis narasumber/responden, Ibu Kuspah : K, Ibu Elis: E, Bapak Aip: A, dan Bapak Ateng: At. Untuk koding urutan kegiatan dengan penggunaan angka sesuai dengan urutan kegiatan. Kategorisasi dalam penelitian ini adalah Rencana Pelaksanaan Pembelajaran (RPP): R dan Pelaksanaan Pembelajaran: P.

\section{HASIL DAN PEMBAHASAN}

\section{Perencanaan Langkah-Langkah Pendekatan Saintifik pada RPP PAI Berdasarkan Kurikulum 2013 \\ Umumnya \\ pelaksanaan} pembelajaran kurikulum 2013 terdiri dari tiga tahapan utama yaitu kegiatan pendahuluan, kegiatan inti, dan kegiatan penutup. Kegiatan pendahuluan adalah aktivitas untuk mengarahkan pembelajaran dan memotivasi siswa untuk belajar. Kegiatan inti adalah tahapan utama dalam belajar, dimana lima langkah utama pembelajaran saintifik harus muncul pada pemaparan kegiatan inti tersebut yaitu mengamati, menanya, mencari informasi, mengkomunikasikan, dan menyimpulkan. Semua langkah tersebut harus muncul beserta aktivitas yang akan dikerjakan oleh siswa. Terakhir adalah kegiatan penutup yang merupakan aktivitas pemantapan untuk penguasaan materi ajar yang dapat berupa rangkuman dan arahan tindak lanjut yang harus dikerjakan untuk aplikasi pengetahuan yang telah diperoleh (Sani, 2014, hal. 281).

Pada prinsipnya, ketiga dokumen RPP yang dikaji telah memiliki isi dan bobot yang sama. Setiap RPP sudah memenuhi ketentuan langkah-langkah pembelajaran yang disusun berdasarkan sistematika RPP 2013. Adapun di dalam RPP sudah mencakup kegiatan pendahuluan, kegiatan inti, dan kegiatan penutup. Pada kegiatan inti sudah muncul 
kegiatan mengamati, menanya, mencari informasi, mengkomunikasikan, dan menyimpulkan.

Kegiatan pendahuluan merupakan awal dari pembelajaran yang akan dimulai. Setiap guru wajib melaksanakan setiap langkah yang ada pada poin kegiatan pendahuluan. Pada umumnya di setiap RPP, melaksanakan langkah kegiatan yang sama karena hal ini biasa dilakukan oleh guru sebelum mulai pembelajaran. Menurut Ridwan Abdullah Sani (2014 : 281-282), dalam setiap kegiatan pendahuluan, terdapat empat kegiatan yang harus dilaksanakan oleh guru, yaitu orientasi, apersepsi, motivasi, dan pemberian acuan. Selanjutnya adalah pembahasan kegiatan inti pada RPP (DR.2) :

\section{- Kegiatan Inti}

a. Mengamati

1. Membaca dan mencermati teks bacaan tentang materi pengertian iman kepada Nabī dan Rasūl, perbedaan Nabī dan Rasūl serta nama-nama Nabī dan Rasūl.

2. Mengamati gambar atau tayangan yang terkait dengan pengertian iman kepada Nabī dan Rasūl, perbedaan Nabī dan Rasūl serta nama-nama Nabī dan Rasūl.

3. Menyimak dan membaca penjelasan mengenai pengertian iman kepada Nabī dan Rasūl, perbedaan Nabī dan Rasūl serta nama-nama Nabī dan Rasūl.

b. Menanya

1. Mengajukan pertanyaan hal-hal tentang pengertian iman kepada Nabī dan Rasūl, perbedaan Nabī dan Rasūl serta nama-nama Nabî dan Rasūl.

2. Menunjuk salah seorang siswa secara acak untuk mengajukan pertanyaan tentang pengertian iman kepada Nabī dan Rasūl, perbedaan Nabī dan Rasūl serta nama-nama Nabī dan Rasūl.

\section{Mengajukan pertanyaan tentang} pengertian iman kepada Nabī dan Rasūl, perbedaan Nabī dan Rasūl serta nama-nama Nabī dan Rasūl.

c. Mengeksperimen/Mengeksplorasi

1. Menggali informasi dan data tentang pengertian iman kepada Nabī dan Rasūl, perbedaan Nabī dan Rasūl serta nama-nama Nabī dan Rasūl berbagai sumber.

d. Asosiasi

1. Menganalisis informasi dan data tentang pengertian iman kepada Nabī dan Rasūl, perbedaan Nabī dan Rasūl serta nama-nama Nabī dan Rasūl

2. Menyimpulkan informasi dan data tentang pengertian iman kepada Nabī dan Rasūl, perbedaan Nabī dan Rasūl serta nama-nama Nabī dan Rasūl

e. Komunikasi.

1. Memaparkan hasil temuan tentang informasi dan data tentang pengertian iman kepada Nabī dan Rasūl, perbedaan Nabī dan Rasūl serta nama-nama Nabī dan Rasūl 
Kegiatan inti yang pertama dalam langkah pembelajaran saintifik adalah mengamati. Banyak kegiatan yang dapat dilakukan guru untuk mengimplementasikan proses mengamati ini. Cara yang digunakan guru menurut RPP ini adalah dengan membaca buku bacaan materi, mengamati gambar atau tayangan tentang materi, dan menyimak penjelasan guru. Hal ini dapat dilakukan dengan bimbingan guru agar dapat berjalan baik, untuk lebih jelas gambaran tentang pelaksanaannya akan dijelaskan pada poin berikutnya di dalam pelaksanaan pembelajaran.

Selanjutnya adalah kegiatan menanya, dalam RPP ini dilaksanakan setelah kegiatan mengamati selesai. Guru telah menjelaskan materi pada kegiatan mengamati dan siswa menyimak apa yang guru paparkan, setelah itu dilanjutkan dengan sesi tanya-jawab antara guru dan siswa, siswa diberi kesempatan untuk bertanya tentang materi yang baru saja dijelaskan. Setiap siswa dipersilahkan mengajukan pertanyaan tentang materi yang belum dipahami. Kegiatan dilanjutkan dengan proses ketiga yaitu mencari data dan informasi tentang materi ajar dari berbagai sumber. Guru biasanya mengizinkan siswa untuk mengakses internet guna mencari informasi yang lebih dalam sehingga tidak terpaku pada buku paket yang ada.

Langkah keempat yaitu kegiatan mengasosiasi. Dalam hal ini, siswa berdiskusi dengan teman kelompoknya untuk menganalisis informasi yang di dapat tentang materi dan langsung menyimpulkan sendiri poin-poin penting yang terdapat pada materi tersebut. Langkah terakhir adalah mengkomunikasikan, kegiatan ini biasanya dilakukan dengan presentasi kelompok. Setiap kelompok harus mempresentasikan hasil analisis dan diskusi tentang materi atau hasil temuan yang mereka dapat selama proses pencarian informasi dan diskusi, kemudian dipresentasikan di depan kelas.

untuk $\begin{array}{r}\text { Kegiatan penutup perlu dilakukan } \\ \text { memantapkan penguasaan }\end{array}$ pengetahuan siswa dengan mengarahkan siswa dalam menyimpulkan bersama-sama materi pembelajaran. Agar siswa dapat menangkap poin penting yang harus diingat dan dihafal untuk pembelajaran selanjutnya. Kemudian guru melakukan refleksi terhadap pembelajaran, biasanya dilakukan dengan menemukan manfaat pembelajaran untuk kehidupan sehari-hari siswa, sehingga siswa dapat mengamalkan apa yang telah diajarkan. Dalam RPP tersebut terdapat pemberian reward pada kelompok terbaik, hal ini sangat bagus untuk dilakukan agar siswa semakin semangat dalam belajar dan terus termotivasi untuk selalu berprestasi. Selanjutnya, guru harus menginformasikan materi yang akan dibahas pada pertemuan mendatang, agar siswa dapat mempersiapkan materi sebelum pembelajaran. Tentu harus ada pemberian tugas dan tindak lanjut, agar siswa senantiasa kembali mempelajari apa yang telah disampaikan di dalam kelas. Untuk menutup pembelajaran, guru membimbing siswa bersama-sama berdoa setelah belajar, agar menjadi pembiasaan bagi siswa untuk selalu berdoa setelah mengerjakan sesuatu.

Langkah pembelajaran saintifik sudah terdapat juga pada RPP yang lain di setiap pertemuannya. Hal yang membedakan hanya materi ajar yang dibawakan pada setiap pertemuan pasti berbeda sehingga langkah-langkah saintifik yang ada disesuaikan kegiatannya dengan materi pembahasan. Pada prinsipnya langkah-langkah pembelajaran ini memiliki inti yang sama yaitu mengamati, menanya, 
mencari informasi, menyimpulkan, dan mengkomunikasikan.

Komponen terakhir RPP dalam kurikulum 2013 adalah penilaian hasil pembelajaran. Pada bagian ini harus dituliskan secara jelas jenis/ragam/prosedur/bentuk penilaian yang akan digunakan untuk mengukur ketercapaian tujuan pembelajaran. Selain itu, harus dituliskan juga instrumen penilaian dan kunci jawaban atau pedoman penilaian yang akan digunakan. Penilaian harus mencakup tiga ranah, yaitu sikap, keterampilan, dan pengetahuan (Abidin, 2014, hal. 303-304).

Narasumber mengatakan bahwa pada penilaian pembelajaran juga terdapat penilaian proses dan penilaian hasil. Penilaian proses biasanya dilakukan pada saat pembelajaran berlangsung, misalnya keaktifan di dalam kelas sedangkan penilaian hasil dilaksanakan setelah pembelajaran, misalnya evaluasi pembelajaran dalam bentuk tertulis, lisan, maupun praktik.

Beberapa guru dalam wawancara mengatakan bahwa rangkaian penilaian proses pembelajaran ini sangat rumit. Mereka mengeluhkan banyaknya format penilaian yang harus diisi oleh guru untuk setiap anaknya, sedangkan guru tidak hanya mengajar satu kelas, tetapi banyak kelas dan setiap siswa harus memiliki format/jurnalnya masing-masing. Hal ini yang dirasa rumit dan tidak sederhana. Menurut pendapat narasumber, seharusnya format penilaian ini dapat lebih disederhanakan lagi. Namun walaupun begitu, guru selalu melaksanakan diskusi dengan guru lainnya untuk sharing tentang cara penilaian pembelajaran yang baik dan benar, agar dapat lebih mahir lagi dalam menangani masalah penilaian ini.

\section{Pelaksanaan Langkah-Langkah Pendekatan Saintifik pada Pembelajaran PAI}

\section{a. Langkah guru menstimulasi siswa terhadap konsep yang diajarkan}

Pada kegiatan ini, sebuah objek harus ada untuk dijadikan sebagai bahan pengamatan siswa. Oleh karena itu, guru senantiasa harus memfasilitasi siswa untuk pengamatan ini. Guru menyiapkan objek pengamatan atau benda yang akan diamati dalam pembelajaran sesuai dengan materi ajar. Kreativitas guru dalam memfasilitasi objek pengamatan untuk siswa sangat ditekankan, agar dapat menarik atau menstimulasi siswa dalam belajar, terutama mengembangkan pemikirannya tentang konsep yang akan diajarkan. Banyak sekali objek yang dapat digunakan guru seperti buku, artikel, gambar, video, benda asli, lingkungan, dll. Objek ini dapat disesuaikan dengan materi yang sedang dibahas dan kegiatan atau tugas siswa adalah membaca, menyimak, melihat, mendengar, dan kegiatan lainnya.

Hal ini terjadi pada pelaksanaan proses pembelajaran yang peneliti amati di dua sekolah yang menjadi tempat penelitian. Secara keseluruhan, proses pembelajaran yang dilakukan oleh para narasumber telah mencakup kegiatan mengamati objek dengan baik.Dari hasil observasi peneliti, kegiatan mengamati yang dilakukan guru selama proses pembelajaran yang muncul adalah :

- Melihat tayangan video

- Menyimak presentasi kelompok atau penjelasan guru

- Mengamati power point materi

- Melihat atau mengamati gambar

- Membaca buku 
Cara-cara tersebut sesuai dengan kegiatan mengamati pada pembelajaran saintifik. Melalui penayangan video, guru menstimulasi siswa agar mereka mampu membuat persepsi awal terhadap konsep yang akan diajarkan. Sebelum guru menjelaskan materi, siswa akan mencoba menanggapi seputar tayangan video tersebut atau bertanya tentang video tersebut. Dengan begitu, siswa akan mampu membangun konsep awal materi dan menambah rasa ingin tahu tentang materi. Demikian juga dengan melihat atau mengamati gambar, kegiatan ini diharapkan membuat siswa menjadi ingin tahu lebih tentang hubungan antara gambar yang diamati dan materi yang akan dipelajari. Tujuannya agar siswa belajar menanggapi gambar yang nampak dan hubungannya dengan materi, atau siswa dapat mengajukan berbagai pertanyaan tentang gambar, ini menunjukan rasa ingin tahu siswa tinggi.

Media lain yang dapat digunakan guru untuk menstimulasi siswa adalah peta konsep, power point, atau buku ajar siswa. Guru dapat menyiapkan media tersebut untuk proses mengamati, sebagaimana yang dilakukan narasumber dengan menggunakan media power point (OPA.2). Jika media ini dibuat oleh guru untuk kegiatan mengamati maka tugas siswa adalah menyimak penjelasan guru dan mengamati power point.

\section{b. Langkah guru menstimulasi siswa untuk bertanya tentang konsep yang diajarkan}

Kegiatan guru dalam hal ini adalah mendorong, membimbing, dan menilai kemampuan berpikir siswa, mengarahkan perhatian siswa pada aspek yang belum diketahuinya, membimbing siswa agar dapat mengajukan pertanyaan tentang hasil pengamatan objek, atau membuka kesempatan secara luas kepada siswa untuk bertanya mengenai apa yang sudah dilihat, disimak, dibaca, ketika proses mengamati dilakukan (Hosnan, 2014, hal. 49). Sebagaimana pendapat di atas, narasumber melakukan hal-hal yang sama. Berdasarkan hasil selama observasi peneliti mengikuti pembelajaran, ada beberapa langkah guru dalam menstimulasi siswa untuk bertanya yang muncul ketika pembelajaran berlangsung yaitu:

- Tanya-jawab setelah presentasi selesai dilakukan antara siswa dengan siswa atau per kelompok siswa

- Siswa bertanya kepada guru saat pembelajaran berlangsung (pada proses mengamati dan pemaparan materi dari guru)

- Menstimulasi siswa untuk bertanya dengan reward

Guru memfasilitasi siswa agar mereka bebas bertanya melalui presentasi. Dengan presentasi ini, siswa lebih dulu menjelaskan materi.Kemudianguru membuka sesi tanya jawab bagi siswa lain yang menyimak untuk bertanya dan siswa yang berpresentasi menjawabnya sehingga siswa dapat bertanya apapun tentang materi yang belum dipahaminya dan teman yang lain dapat membantu mencari jawabannya. Keaktifan inilah yang diharapkan, pertanyaan dari siswa dan dijawab oleh siswa. Sebuah pembelajaran bagi mereka agar dapat menemukan jawaban sendiri dari setiap pertanyaan yang diajukan dan tanya-jawab tidak berjalan satu arah, tetapimelibatkan semua siswa. Tugas guru adalah menilai proses tanya-jawab, menilai penanya, dan mengapresiasi penjawab. Sejauh yang diamati peneliti, guru lebih sering diam, memperhatikan, dan menilai siswa ketika proses ini berlangsung. Sementara siswa sangat aktif dan antusias 
dalam tanya jawab ini, bahkan tidak jarang terjadi debat dan kegaduhan dalam jalannya kegiatan.

Selain itu, guru juga memotivasi siswa untuk bertanya ketika proses mengamati berlangsung atau ketika guru sedang menjelaskan. Dalam setiap proses mengamati, guru memberi kesempatan pada siswa untuk bertanya tentang objek atau hal lain yang sedang diamati dan belum dipahami. Dengan demikian, guru dapat menjelaskan jawabannya. Guru juga memberi kesempatan pada siswa yang ingin bertanya ditengah pemaparan materi. Hal ini terjadi hanya satu arah, antara siswa dengan guru atau guru dengan siswa. Beberapa guru menstimulasi siswa dengan sistem reward, biasanya siswa akan lebih antusias apabila dimotivasi dengan reward, seperti nilai atau hal lainnya.

\section{c. Langkah guru memfasilitasi siswa dalam mengumpulkan berbagai informasi terkait konsep yang diajarkan}

Langkah ketiga pembelajaran saintifik adalah mengumpulkan informasi. Proses ini dilakukan dengan menggali dan mengumpulkan informasi dari berbagai sumber. Kegiatan yang dilakukan siswa adalah membaca buku, memperhatikan fenomena atau objek, mencari data/informasi dari internet, atau melakukan eksperimen (Hosnan, 2014, hal. 57). Sebagaimana dijelaskan dalam Permendikbud No. 81a Tahun 2013 yang dikutip oleh M. Hosnan (2014: 57) mencantumkan bahwa aktivitas mengumpulkan informasi dilakukan melalui eksperimen, membaca sumber lain selain buku teks, mengamati objek/kejadian/aktivitas wawancara dengan narasumber, dan sebagainya. Kegiatan mengumpulkan data dan informasi ini dapat dilakukan secara bersamaan dengan proses mengamati. Selama siswa mengamati objek, dari sana mereka juga akan memperoleh informasi, misalnya guru menugaskan siswa untuk membaca buku teks dan menggali informasi tentang materi, ini artinya bahwa ketika siswa membaca buku, dengan otomatis mereka akan mendapatkan informasi.

Sementara guru dapat kegiatan sebagai berikut (Hosnan, 2014, hal. 57):

- Guru harus membuat siswa aktif terlibat dalam kegiatan mengamati, dengan membangun suasana belajar yang semangat dan menyenangkan

- Guru harus menampung semua pendapat siswa dan membimbingnya untuk memperbaiki yang kurang tepat tanpa membuat patah semangat

- Mengoreksi setelah siswa selesai mengungkapkan pendapatnya dan jangan memotong ketika siswa sedang berbicara

- Memfasilitasi siswa dengan sumber data dan informasi agar ia dapat mencari secara mandiri

Berdasarkan hasil observasi, narasumber telah memfasilitasi siswa untuk mencari data dan informasi secara mandiri bersamaam dengan proses pengamatan melalui buku dan internet. Sebagian besar cara yang dilakukan guru adalah menugaskan siswa mencari informasi tentang materi pada buku paket dan internet secara berkelompok. Guru memberi subtema materi yang berbeda pada setiap kelompoknya, kemudian ketika mereka ditugaskan untuk mengamati buku bacaan dan membacanya, pada saat itu pula proses pencarian informasi berlangsung. Informasi dan data yang telah diperoleh dapat dibuat dalam beberapa cara, diantaranya dirangkum dengan menuliskan poin-poin penting materi, dibuat dalam 
bentuk power point untuk dipresentasikan, dibuat dalam bentuk makalah, atau dibuat dalam bentuk peta konsep.

\section{d. Langkah guru membimbing siswa untuk membangun argumentasi dari konsep yang diajarkan}

Langkah keempat adalah kegiatan mengkomunikasikan. Menurut M. Hosnan (2014: 76) kegiatan ini dapat dilakukan dengan cara menuliskan atau menceritakan apa yang ditemukan dalam kegiatan mencari informasi, mengasosiasikan dan menemukan pola. Hasil tersebut disampaikan di depan kelas dan dinilai oleh guru sebagai hasil belajar siswa atau kelompok siswa. Masih dalam pendapat dan sumber yang sama, berikut beberapa kegiatan yang dapat dilakukan dalam proses mengkomunikasikan :

1) Siswa membacakan hasil kerja mereka di depan kelas

2) Setiap kelompok mendengarkan dengan baik presentasi yang dibawakan kelompok lain

3) Setiap anggota kelompok bergiliran membacakan hasil kerja kelompoknya

4) Guru mengarahkan dan memastikan kegiatan ini berjalan dengan baik

5) Semua siswa harus terlibat aktif dalam mengkomunikasikan ini kegiatan

Berdasarkan hasil observasi dan wawancara, setiap kegiatan untuk mengimplementasikan proses keempat ini adalah dengan cara presentasi kelompok atau individual. Presentasi adalah cara yang utama dan paling sering dilakukan oleh guru ketika proses mengkomunikasikan berlangsung. Melalui presentasi siswa, guru dapat melihat kemampuan berbicara siswa di depan umum dan membelajarkan mereka tampil berani bicara serta terampil dalam berkomunikasi. Hal ini sesuai dengan kompetensi yang diharapkan pada proses ini yaitu mengembangkan keberanian, toleransi, berpikir sistematis, mengungkapkan pendapat dengan singkat dan jelas, serta dapat mengembangkan kemampuan berbahasa yang baik dan benar. Jadi, kegiatan presentasi dalam setiap pembelajaran merupakan langkah rutin yang dilakukan guru untuk membimbing siswa dalam membangun keberanian berargumentasi.

Seluruh kegiatan observasi yang dilakukan peneliti dalam pembelajaran PAI, mengimplementasikan proses mengkomunikasikan ini dengan cara presentasi. Seperti pada saat materi pembelajaran "Pertumbuhan Ilmu Pengetahuan pada Masa Abbasiyyaћ", setiap kelompok mempresentasikan hasil temuannya melalui media power point dengan mencantumkan poin penting yang akan dibahas. Mereka menampilkan gambar-gambar tokoh pada masa Abbasiyyah untuk mendukung penjelasan materi atau menampilkan peta wilayah kekuasaan Abbasiyyah dan struktur kepemerintahannya. Siswa sudah tampil kreatif dengan adanya media dan objek yang dimanfaatkan sebagai pendukung presentasinya.

Selain itu, guru menstimulasi kekreatifan siswa dengan menugaskan mereka membuat peta konsep pada materi sejarah sehingga mereka tidak hanya membaca atau bercerita. Namun juga menghasilkan kreasi berupa peta konsep yang beragam sesuai dengan submateri yang ditugaskan pada setiap kelompok. Langkah ini mendorong siswa untuk lebih berkreasi, sementara guru menilai kerja sama yang dilakukan kelompok selama proses pembuatan peta konsep tersebut. Biasanya guru membawa jurnal penilaian siswa untuk diisi sebagai nilai proses 
pembelajaran siswa. Setelah peta konsep selesai, setiap kelompok mempresentasikannya sesuai dengan apa yang ada di dalam peta konsep. Dalam setiap presentasi, guru selalu mendorong siswa agar berbicara secara bergantian sehingga tidak hanya satu atau beberapa orang saja yang berbicara menyampaikan materi, tetap semua anggota kelompok harus dapat bagian dalam penyampaiannya. Narasumber pun berpendapat sama bahwa harus ada pembagian tugas dalam presentasi, agar rasa percaya diri dan keberanian siswa lebih terasah.

\section{e. Langkah guru membimbing siswa untuk menyimpulkan konsep yang diajarkan}

Langkah terakhir dari pembelajaran saintifik adalah kegiatan menyimpulkan. Kemampuan menyimpulkan merupakan kemampuan membuat intisari atau seluruh proses kegiatan pembelajaran yang telah dilaksanakan. Simpulan biasanya harus menjawab poin-poin inti materi yang telah dipelajari pada pertemuan itu (Abidin, 2014, hal. 140). Dalam menyimpulkan materi pembelajaran, biasanya ada yang disampaikan pada saat akhir kegiatan inti atau pada saat kegiatan penutup. Kegiatan ini dapat dilakukan oleh siswa secara mandiri, guru, atau bersama-sama antara guru dan siswa.

Berdasarkan observasi pembelajaran, narasumber melakukan hal yang sama pada saat pembelajaran. Beberapa narasumber menugaskan siswa untuk menyimpulkan sendiri apa yang telah mereka diskusikan dan menyampaikan simpulannya pada saat presentasi (OPA.1, WA.1). Beberapa pendapat mengatakan bahwa proses menyimpulkan dilakukan bersamaan dengan proses mengasosiasi atau menganalisis data sehingga ketika siswa selesai membuat hasil diskusi, pada saat itu juga mereka menyimpulkan data hasil temuan tersebut sebelum dipresentasikan. Hasil temuan dapat dapat diartikan juga sebagai simpulan yang dibuat oleh siswa dan selanjutnya menjadi pengetahuan yang benar-benar dikontruksi oleh siswa sendiri (Abidin, 2014, hal. 143).

Kegiatan ini dapat juga dilakukan pada saat kegiatan penutup. Artinya setelah kegiatan inti selesai, guru bersama-sama dengan siswa menyimpulkan materi yang telah disampaikan pada pertemuan itu. Biasanya, guru bertanya tentang poin inti materi dan siswa menjawabnya. Redaksi yang digunakan seperti "Ada berapa syarat sah șalat Jum'ah dan sebutkan?" kemudian siswa menjawabnya. Dalam proses menyimpulkan ini, guru juga memberi tambahan informasi materi dan penguatan. Penguatan materi berarti guru menyebutkan kembali dengan tegas poin inti materi yang harus diingat dan dihafal siswa, juga memberi penjelasan tambahan tentang apa yang belum dibahas siswa pada saat presentasi.

Pada saat kegiatan menyimpulkan, guru dapat sekaligus memberi penjelasan tentang materi tambahan yang penting untuk dibahas. Dengan teknik ceramah, guru menjelaskan materi secara satu arah pada siswa. Sementara siswa menyimak atau menulis rangkuman dari apa yang dijelaskan guru. Pada saat itulah guru menyampaikan kesimpulan pembelajaran. Beberapa cara tersebut dilakukan oleh narasumber dalam mengaplikasikan kegiatan terakhir ini.

Keterampilan menyimpulkan akan muncul jika siswa dapat fokus pada materi yang disampaikan selama pembelajaran berlangsung. Maka guru harus selalu memperhatikan setiap siswanya agar mereka tetap fokus selama pembelajaran, dan diakhir pembelajaran guru harus mengecek pemahaman siswa dengan cara 
menyimpulkan materi pembahasan pada saat itu. Baik secara individu ataupun kelompok, dengan demikian akan terlihat siswa mana yang telah paham dan tidak. Pencatatan dalam proses menyimpulkan juga sangat penting, karena siswa sewaktuwaktu dapat lupa dan catatan itulah yang akan mengingatkannya kembali.

\section{KESIMPULAN}

$\begin{array}{ccc} & \text { Hasil penelitian menunjukan bahwa } \\ \text { guru PAI mengimplementasikan }\end{array}$

pendekatan saintifik pada proses pembelajaran menggunakan konsep student center artinya guru hanya membimbing, menilai dan mengawasi, sementara siswa harus aktif selama pembelajaran berlangsung. Media adalah alat yang digunakan untuk mengimplementasikan proses mengamati, melalui pengamatan terhadap media akan menstimulasi siswa untuk bertanya dan berargumentasi berdasarkan pengamatannya. Guru memfasilitasi siswa untuk mencari berbagai data dan informasi terkait materi dan seputar pertanyaannya, sehingga tidak hanya guru yang dapat menjawab, tapi siswa juga mampu mencari tahu sendiri informasinya melalui buku atau internet. Setelah data di dapat, siswa berdiskusi dan mengasosiasi secara berkelompok untuk menganalisis data, kemudian data hasil diskusi dipresentasikan dan disimpulkan. Upaya guru untuk dalam mengimplementasikan pendekatan saintifik ini dapat dilihat dari bagaimana cara menyusun perencanaan pembelajaran (RPP) dan bagaimana melaksanakan pembelajaran saintifik proses.

Implikasinya bahwa pembelajaran saintifik ini sudah bisa dijalankan oleh guru PAI di SMPN 2 dan SMPN 5 kota Bandung. Guru telah berupaya untuk mengimplementasikan pembelajaran saintifik dengan baik. Terlaksananya pendekatan saintifik di SMPN 2 dan SMPN 5 kota Bandung pada proses pembelajaran menunjukan bahwa tidak semua guru masih kebingungan dalam ruang kurikulum 2013 ini. Dengan adanya beberapa sekolah yang masih menggunakan kurikulum 2013, menandakan bahwa sebenarnya guru-guru mampu melaksanakan kurikulum 2013, sehingga pemerintah tidak harus mengembalikan ke KTSP. Adapun dalam pelaksanannya pasti terdapat kesulitankesulitan, tetapi sejauh ini para guru dapat mengatasinya dengan cara bermusyawarah dalam MGMP PAI atau lebih banyak sharing dengan rekan guru lain yang lebih tahu. 


\section{DAFTAR PUSTAKA}

Abidin, Y. (2014). Desain Sistem Pembelajaran dalam Konteks Kurikulum 2013. Bandung: Refika Aditama.

Gunawan, I. (2013). Metode Penelitian Kualitatif. Jakarta: Bumi Aksara.

Hosnan, M. (2014). Pendekatan Saintifik dan Kontekstual dalam Pembelajaran Abad 21. Bogor: Ghalia Indonesia.

Nasution, S. (2009). Metode Research. Jakarta: Bumi Aksara.

Puspitarini, M. (2014, 10 16). Tiga Masalah Guru dalam Implementasi Kurikulum 2013. Dipetik 01 13, 2015, dari www.okezone.com:

m.okezone.com/read/2014/10/16/65/1 052959/tiga-masalah-guru-dalamimplementasi-kurikulum-2013

Sani, R. A. (2014). Pembelajaran Saintifik untuk Implementasi Kurikulum 2013. Jakarta: PT Bumi Aksara.

Sarosa, S. (2012). Penelitian Kualitatif: Dasar-Dasar. Jakarta: PT Indeks.

Suryabrata, S. (2012). Metodologi Penelitian. Jakarta: Rajawali Pers. 